\title{
DETERMINATION OF SOME CHEMICAL RESIDUES IN THE EFFLUENTS OF PHARMACEUTICAL INDUSTRY
}

Khalil, M. M. ${ }^{(1)}$; Abdel Razek, T. M. ${ }^{(2)}$ and Tawfik, E. M. ${ }^{(3)}$

1) Faculty of Science, Ain Shams University 2) Institute of Environmental Studies and Research, Ain Shams University 3) Drug Holding Company

\begin{abstract}
Widespread occurrence of pharmaceuticals has started to attract attention as aquatic micropollutants that might have been affecting the ecological system in trace amounts. The risks associated with their introduction into wildlife habitats is becoming an important issue for both regulators and the pharmaceutical industry, because of incomplete elimination of pharmaceuticals wastewater and their metabolites. In this work monitoring of some pharmaceutical residues in industrial wastewater such as (caffeine, paracetamol, dexamethasone and naproxen) was carried out. The identification and quantification of chemical and pharmaceutical residues was investigated using GC/MS spectrometer and liquid chromatography-based tandem mass spectrometry LC/MS/MS spectrometer with electrospray ionization (ESI) .The study recorded the presence of different types of pharmaceutical residues with different concentration levels in wastewater .The concentration level of dexamethasone in wastewater were detected at $254 \mathrm{ng} / \mathrm{ml}$, for paracetamol at $7325 \mathrm{ng} / \mathrm{ml}$, for caffeine at $9356 \mathrm{ng} / \mathrm{ml}$ and for naproxen at $2 \mathrm{ng} / \mathrm{ml}$. These concentrations representing about 500 fold higher than international safety margin of treated wastewater.

Keywords:- Pharmaceuticals, Micropollutants, Monitoring and wastewater.
\end{abstract}

\section{INTRODUCTION}

Water comprises four-fifths of the human body and is one of the most fundamental factors involved in many vital human interactions and studies have shown that humans can't live without drinking water more than three days (Helmy, 2009). 
Drugs and pharmaceuticals have been used for decades in the treatment of diseases, but the surprise was that there are few studies have been made about their environmental and health effect, even if specifications of drinking water does not include any indication of the limits of toxicity and damage to more than 7000 compound drug is described medically (Al-Ananzah,2010).

Pollution with pharmaceutical residues is one form of water pollution and recent researches have revealed that there are pharmaceutical residues in the water which threaten human health as a result of exposure to long-term low doses of pharmaceutical residues, especially since most of these materials are characterized by their resistance to degradation and last for many years to be degraded (Abdel Maged, 2001).

Over the last few decades, the occurrence of micro-pollutants in the aquatic environment has become a worldwide issue of increasing environmental concern. Micropollutants, also termed as emerging contaminants or emerging environmental pollutants, consist of a vast and expanding array of anthropogenic as well as natural substances. These include pharmaceuticals, personal care products, steroid hormones, industrial chemicals, pesticides and many other emerging compounds. They are commonly present in waters at trace concentrations, ranging from a few ng/L to several $\mu \mathrm{g} / \mathrm{L}$. The low concentration and diversity of micropollutants not only complicate the associated detection and analysis procedures but also create challenges for water and wastewater treatment processes (Luo et al., 2014). 
Among emerging pollutants, a particular attention focuses on pharmaceuticals and hormones because they may exert their activity at the very low ng/L range (Vulliet and Cren-Olivé, 2011). Most of the literature published has been on the treatment of municipal wastewater. However, there is a growing body of research that looks at the presence of active pharmaceutical ingredients in industrial wastewater (Deegan et al., 2011).

As pharmaceuticals were consumed in high quantities worldwide, in the range of tons per year per one pharmaceutical compound depending on the size of a country. The expectations are that these amounts will only keep increasing because of an improving health care system, discoveries of new drugs and longer life expectations of people (Van der Aa et al., 2011). Pharmaceuticals enter the environment via human or animal secretions or disposition of domestic drugs, ends up in wastewater purification plants. Their presence in water can also be attrbiuted to waste of pharmaceutical industry, waste of hospital and therapeutic drugs. They are not only released into the environment after use but some might disposed during manufacture or as unused or expired drugs. Certain pharmaceutical production facilities in pharmaceutical industries were found to be sources of much higher environmental concentrations than those caused by the usage of drugs. (Shalini et al., 2010). It has been estimated that up to half of the pharmaceutical wastewater produced worldwide is released without any treatment (Enick and Moore, 2007), these pollutants are non-biodegradable.

Studies reveled that even small amounts (ng / L) of some pharmaceuticals adverse effect on aquatic communities include endocrine disturbance as the feminization of male fish (Corcoran et al., 2010), 
development of pathogen resistance or development of antibiotic resistant bacteria (Yu et al., 2009). Kolpin et al., 2002 reported the presence of one or more organic wastewater contaminants (OWCs) in $80 \%$ of 139 U.S streams across 30 states during 1999 and 2000 . Barnes et al., 2004 reported the presence of OWCs as lincomycin at conc. $0.05 \mathrm{ng} / \mathrm{ml}$ in central Oklahoma (well 35).

Thomas and Foster, 2005 and Terns et al., 2001 reported the presence of caffeine at conc. $150 \mathrm{ng} / \mathrm{ml} 42 \mathrm{ng} / \mathrm{ml}$, respectively.

Since little is known about the potential chronic hazards associated with long term ingestion of pharmaceutical compounds through drinking water, so it was necessary to study these residues in industrial wastewater, where the presence of these residues in industrial wastewater may affects all the components of the environment .

The aim of this study was to monitor and determine some chemical and pharmaceutical residues in industrial wastewater using GC-MS and the analytical method was used (EPA625),liquid chromatography-based tandem mass spectrometry LC/MS/MS spectrometer with electrospray ionization (ESI) and the analytical method was used (EPA 1694 ). 


\section{MATERIALS AND METHODS}

Monitoring and Determination of some Chemical and Pharmaceutical residues in the effluent of a Pharmaceutical and Chemical Industries facility

\section{A) Materials}

1. Pharmaceutical standards were supplied by The El-Nile Co. for Pharmaceutical and Chemical Industries (El-Nile) Cairo- Egypt . Methanol 99.9\% purity, sodium hydroxide, acetonitrile (ACN) and formic acid from Sigma Aldrich. $\mathrm{HCl} 37 \%$ purity from Fisher.Ultra-pure water was used thought the work (MQ) (MilliQ system; Millipore, USA).

2. Water samples were collected from the wastewater of a pharmaceutical and chemical industries facility in pre-rinsed amber glass bottles .

\section{B) Methods of analysis}

Samples collected from the effluents of a Pharmaceutical and Chemical Industries facility were determined and monitored for chemical and pharmaceutical residues by (EPA 625) using GC/MS/MS . This method is applicable to the determination of extractable organics in municipal and industrial discharges which collected from field in glass container then the water sample is filtered then a measured volume of sample, approximately 1L extracted with methylene chloride at a $\mathrm{pH} 2$ using a separatory funnel. The $\mathrm{pH}$ is adjusted by sulfuric acid. The organic layer (Methylene chloride) extract dried, concentrated to a volume of $1 \mathrm{ml}$ using Rota vapor instrument. Then analyzed by GC (varian 3800) and mass detector (varian320-MS) in full scan. Qualitative identification of the individuals in the extract is performed using the retention time and the relative abundance of the three characteristics masses $(\mathrm{m} / \mathrm{z})$. 
Quantitative analysis is performed by using LC/MS/MS.

Samples were collected from the effluents (before treatment) of a pharmaceutical and chemical Industries facility vacuum filtered through a $0.45-\mu \mathrm{m}$ glass fiber filter then extracted via solid-phase extraction (SPE) (Brosius, 2011) and subsequently analyzed by LC/MS/MS (Agilent's 6410 triple quadruple LC/MS/MS system with ESI). The Agilent MassHunter Workstation software (version: B.01.04) was used for system control and data acquisition. Table (1)

Table (1): Instrument Parameters

\begin{tabular}{|c|c|}
\hline HPLC & MS-MS \\
\hline Agilent 1200 LC system & MS: G6410A QQQ \\
\hline $\begin{array}{l}\text { ZORBAX Eclipse XDB-C18, RRHT, } \\
(4.6 \times 50 \mathrm{~mm}, 1.8 \mu \mathrm{m})\end{array}$ & ionization mode: ESI \\
\hline Column temperature: $\quad 40^{\circ} \mathrm{C}$ & $\begin{array}{l}\text { Mass range: } 125 \text { to } 800 \\
\text { amu }\end{array}$ \\
\hline $0.1 \%$ Formic acid/H2O & Scan time: $300 \mathrm{~ms}$ \\
\hline Acetonitrile $(\mathrm{ACN})$ & Capillary: \\
\hline $0.3 \mathrm{~mL} / \mathrm{min}$ & Nebulizer P: \\
\hline \multirow{3}{*}{$\begin{array}{l}\mathrm{T}=0, \mathrm{~A}=100 \%, \mathrm{~B}=0 \% \\
\mathrm{~T}=15, \mathrm{~A}=0 \%, \mathrm{~B}=100 \% \\
\mathrm{~T}=20, \mathrm{~A}=0 \%, \mathrm{~B}=100 \% \\
\mathrm{~T}=21.5, \mathrm{~A}=100 \%, \mathrm{~B}=0 \%\end{array}$} & Drying gas: $\quad 9 \mathrm{~L} / \mathrm{min}$ \\
\hline & Gas temperature: $350^{\circ} \mathrm{C}$ \\
\hline & \multirow[t]{2}{*}{ Skimmer: $\quad 35 \mathrm{~V}$} \\
\hline Injection volume: $\quad 1.0 \mu \mathrm{L}$ & \\
\hline
\end{tabular}

Source: (Meng, 2008) 


\section{RESULTS AND DISCUSSIONS}

Qualitative analysis of wastewater showed that there are many organic wastewater contaminants (OWCs) as shown in Figures (1,2,3 and 4) and Table 2 .

Quantitative analysis of selected four compounds of organic wastewater contaminants (OWCs) shown in Figures (5,6 and 7) and Table 3.

Thomas and foster (2005) and Terns et al. (2001) reported the presence of caffeine at concentration $150 \mathrm{ng} / \mathrm{ml}, 42 \mathrm{ng} / \mathrm{ml}$, respectively. Jones, et al. (2005) found paracetamol and naproxen at nanograms per liter and per ml levels, respectively in a large english sewage treatment plant and in Louisiana. Influent concentrations are likely to be quite variable because they are dependent upon various factors such location, socioeconomic status, pharmaceutical cost, and other demographic data . 
J. Environ. Sci.

Institute of Environmental Studies and Research - Ain Shams University

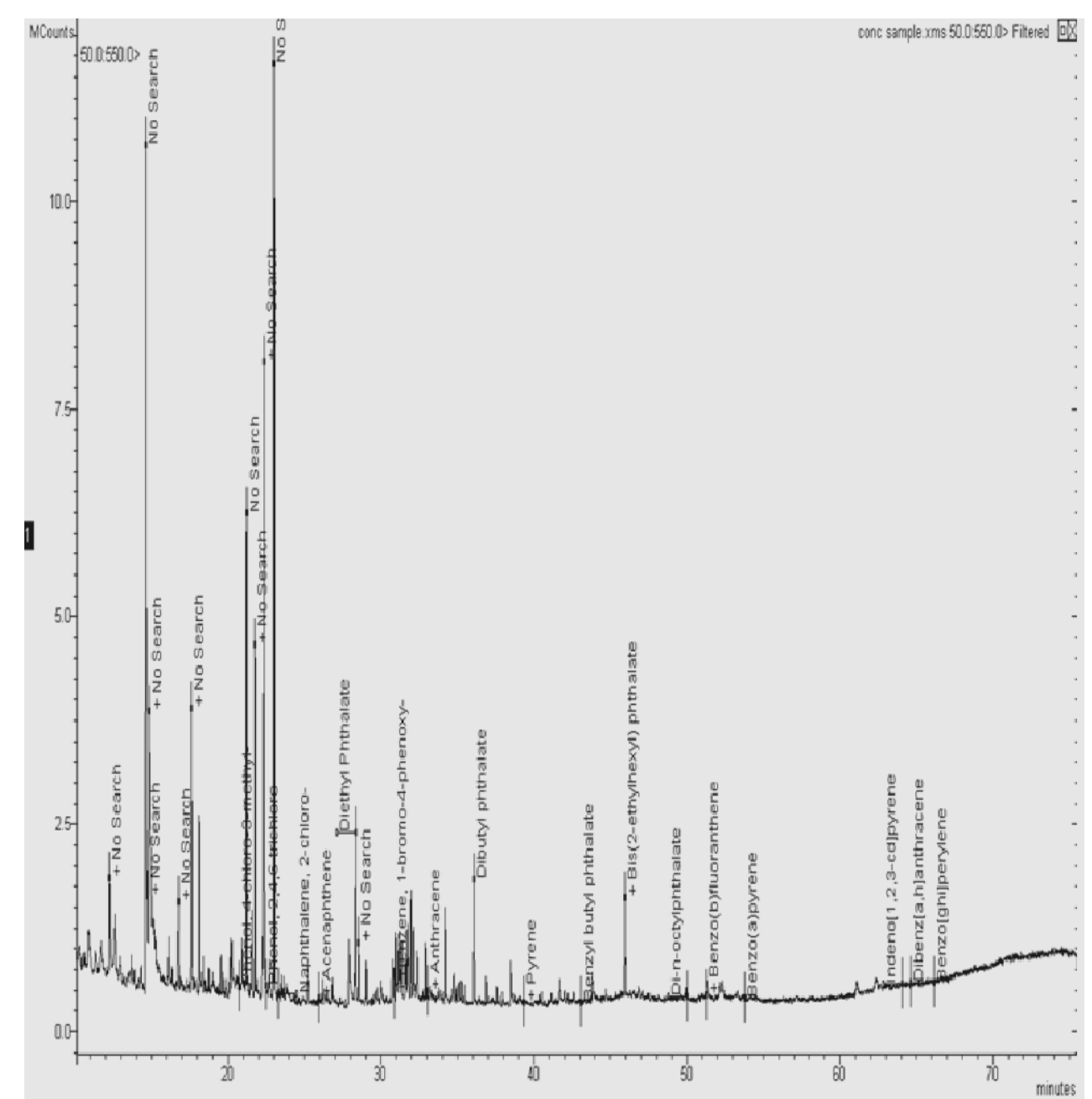

Figure (1):.GC/MS scan for sample (1) 
Khalil, et al.

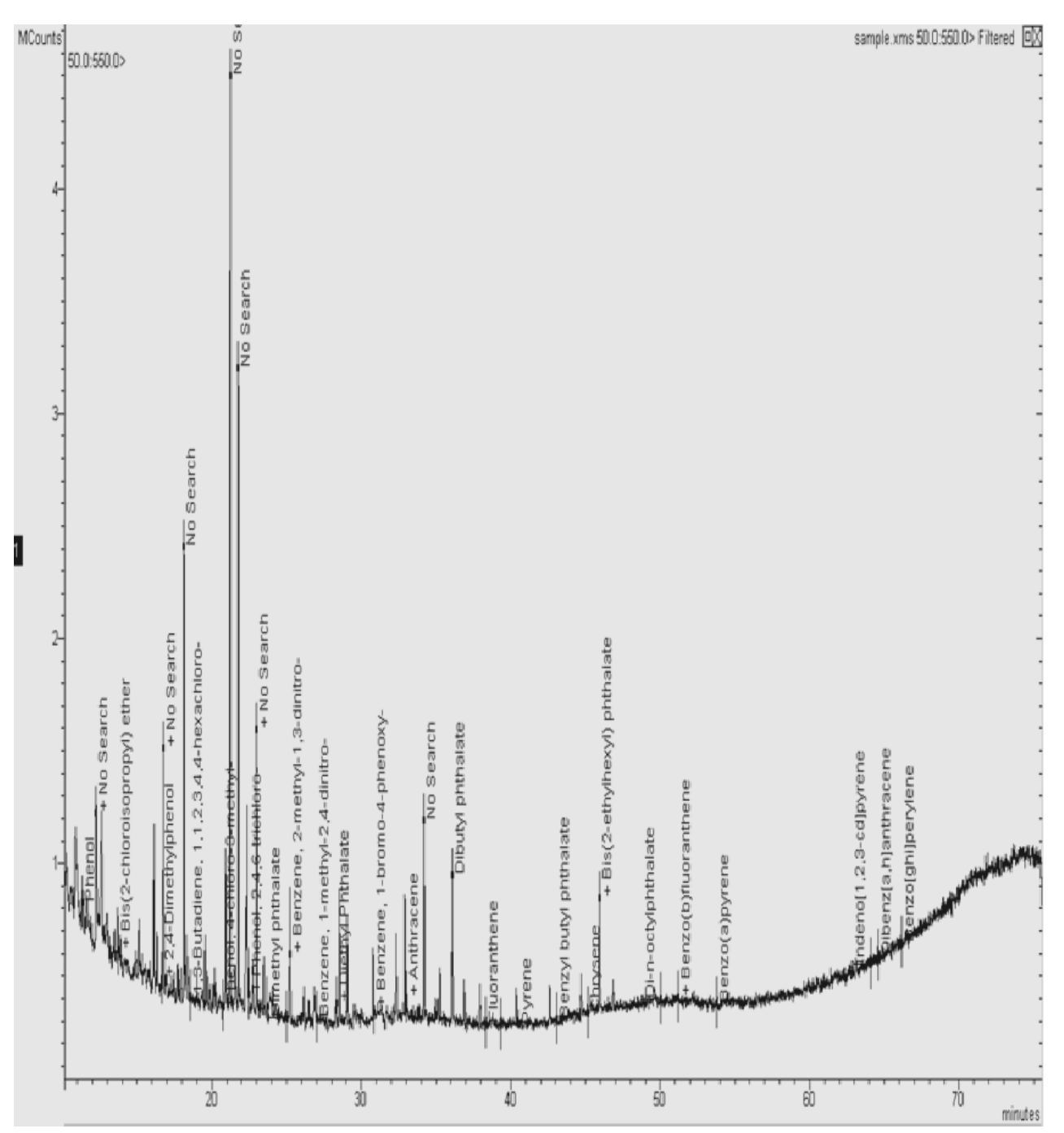

Figure (2):.GC/MS scan for sample (2) 
J. Environ. Sci.

Institute of Environmental Studies and Research - Ain Shams University

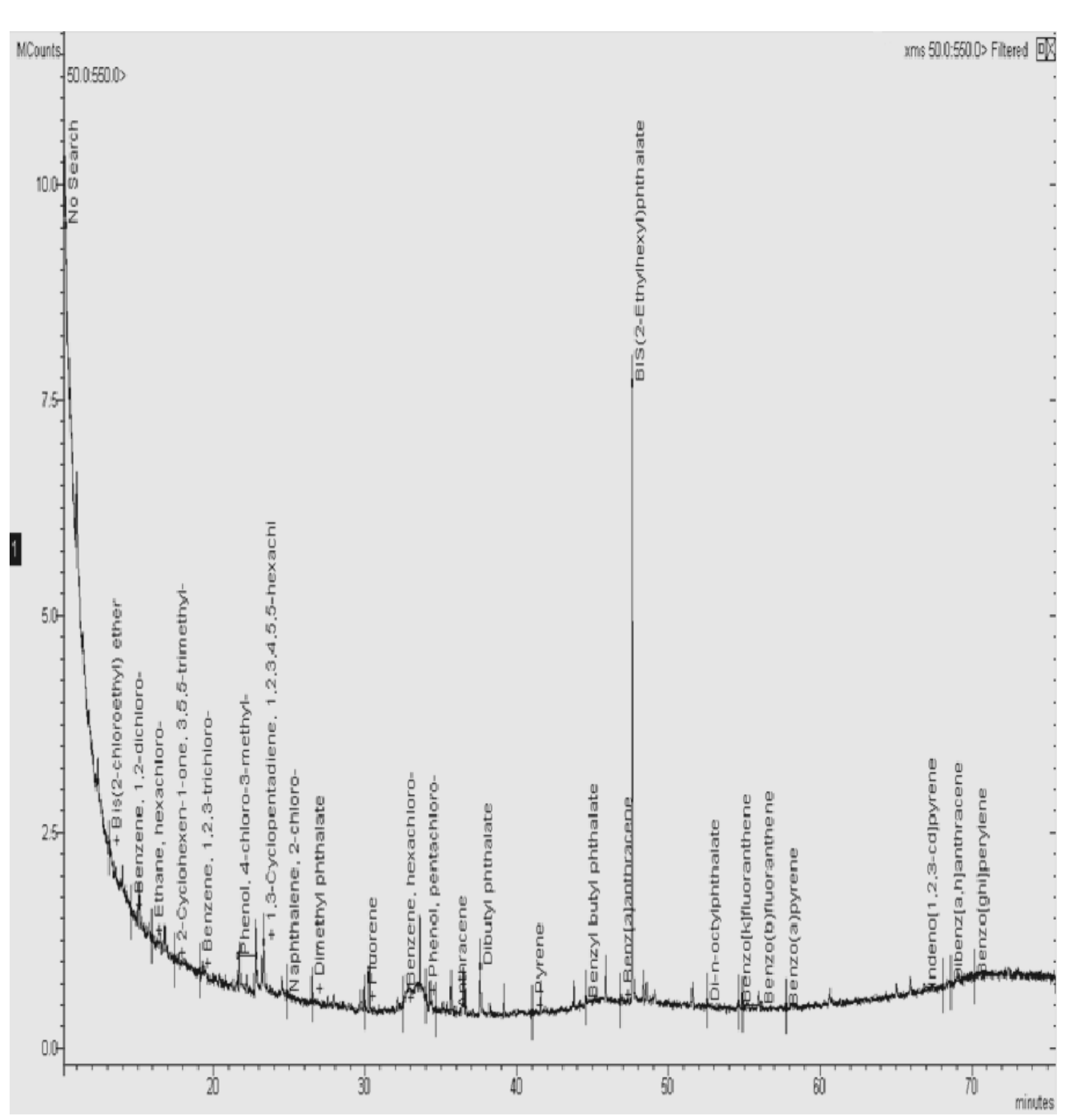

Figure (3):.GC/MS scan for sample (3) 


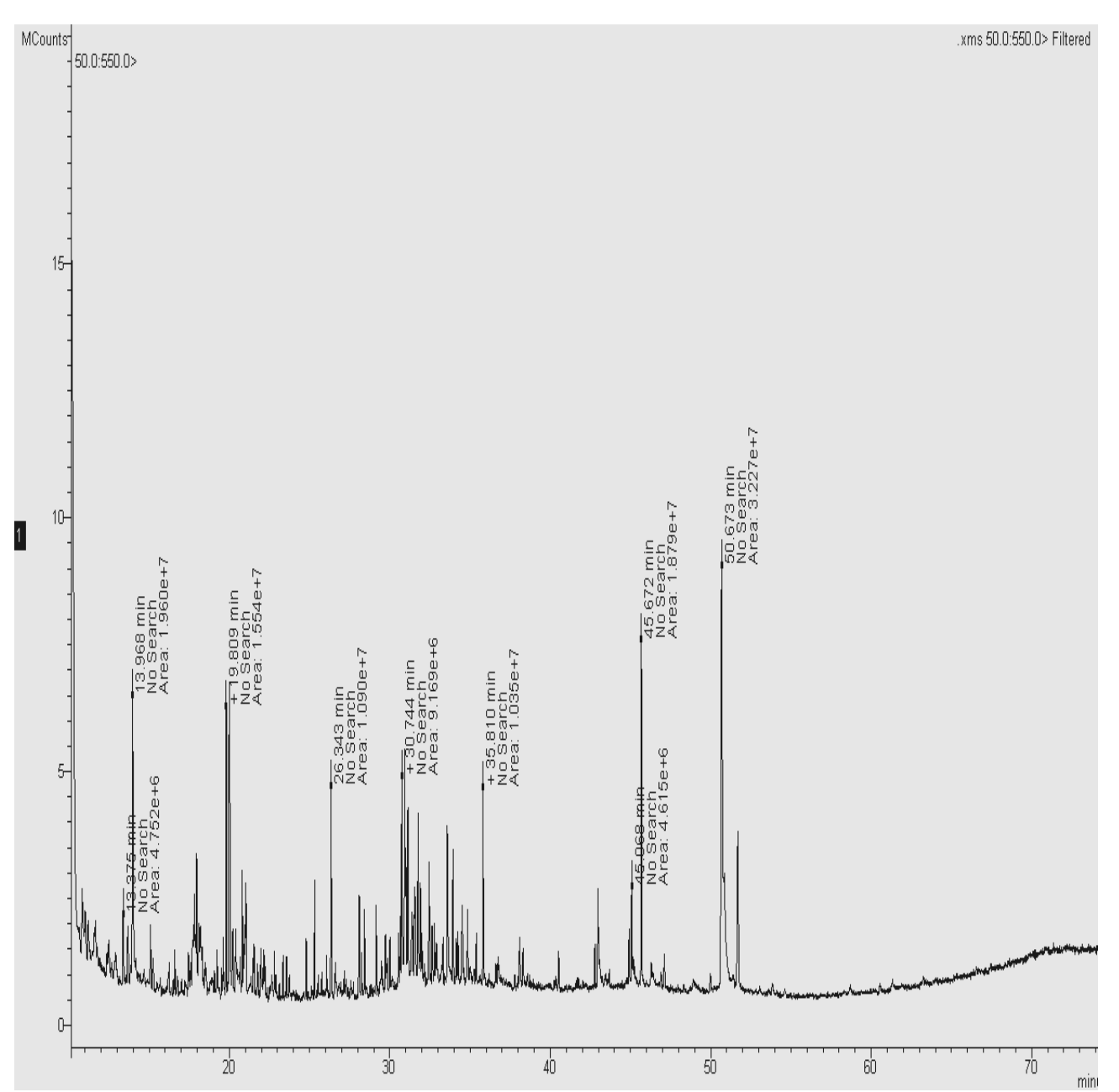

Figure (4):.GC/MS scan for sample (4) 
J. Environ. Sci.

Institute of Environmental Studies and Research - Ain Shams University

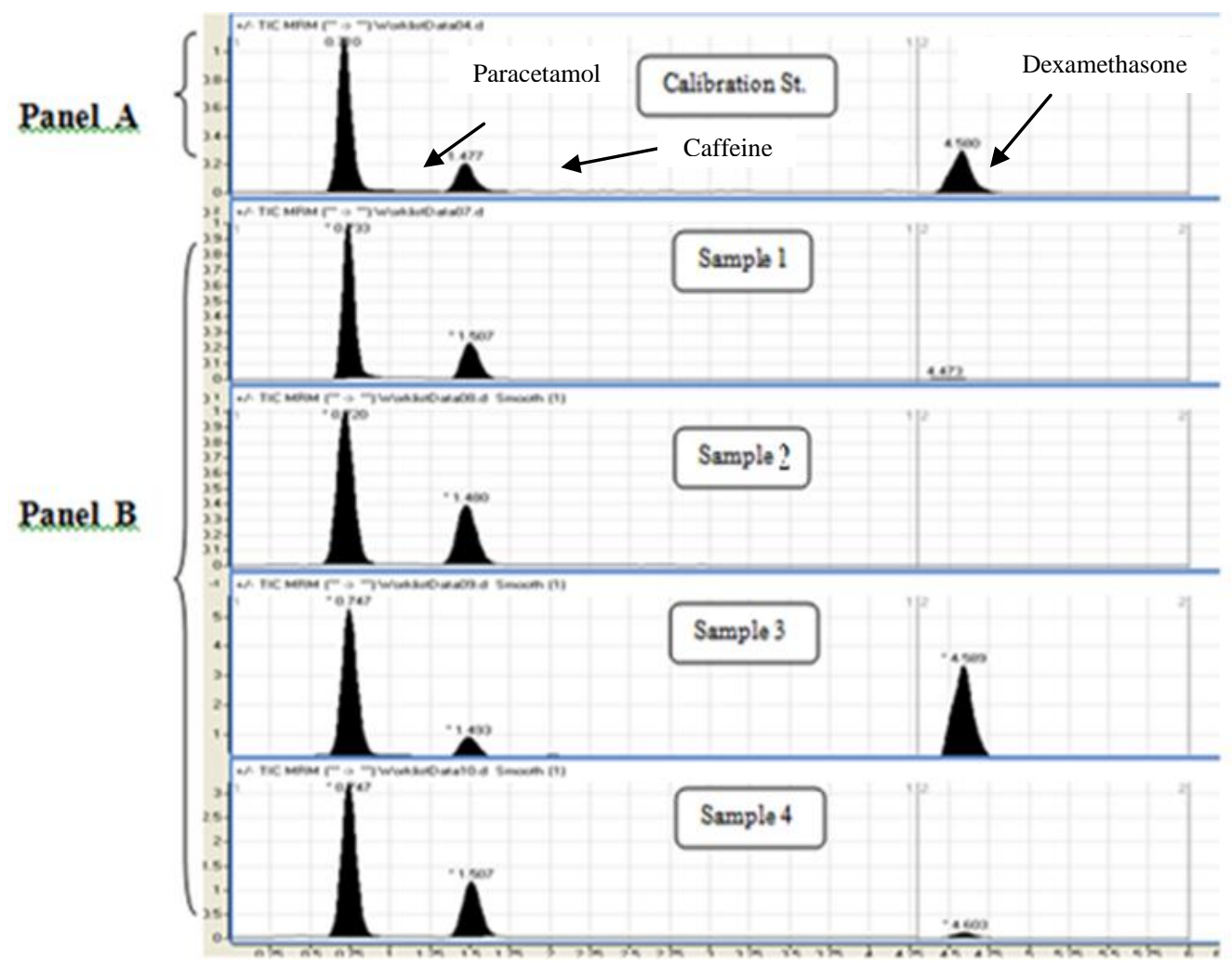

Figure (5): Panel A shows calibration standard of 3 pharmaceutical compounds peaks for (PCM, caffeine and dexamethasone) respectively. Panel B shows 3 industrial wastewater samples compared to panel A in retention time 
Khalil, et al.

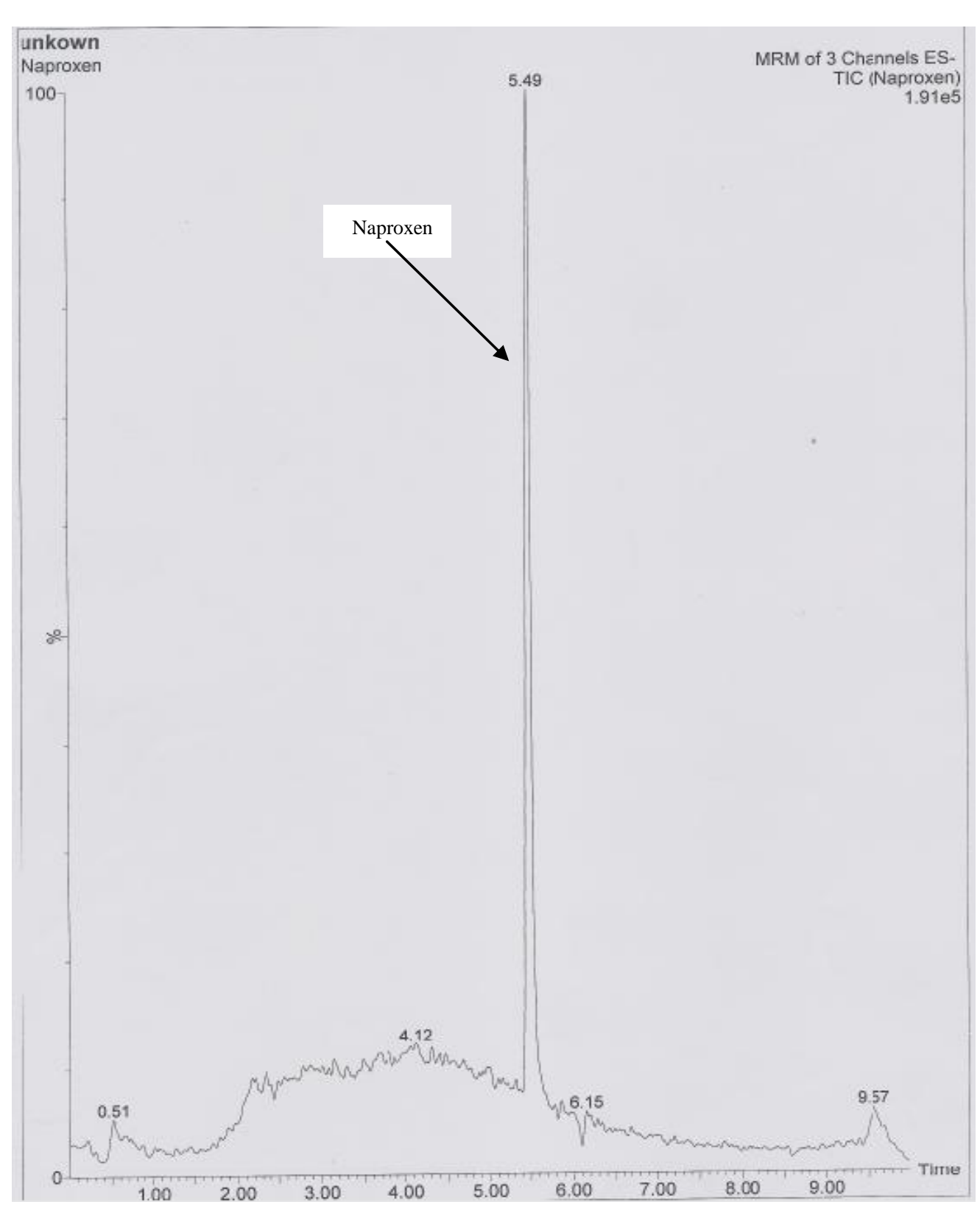

Figure (6): Naproxen chromatogram 1700 ppm 
J. Environ. Sci.

Institute of Environmental Studies and Research - Ain Shams University

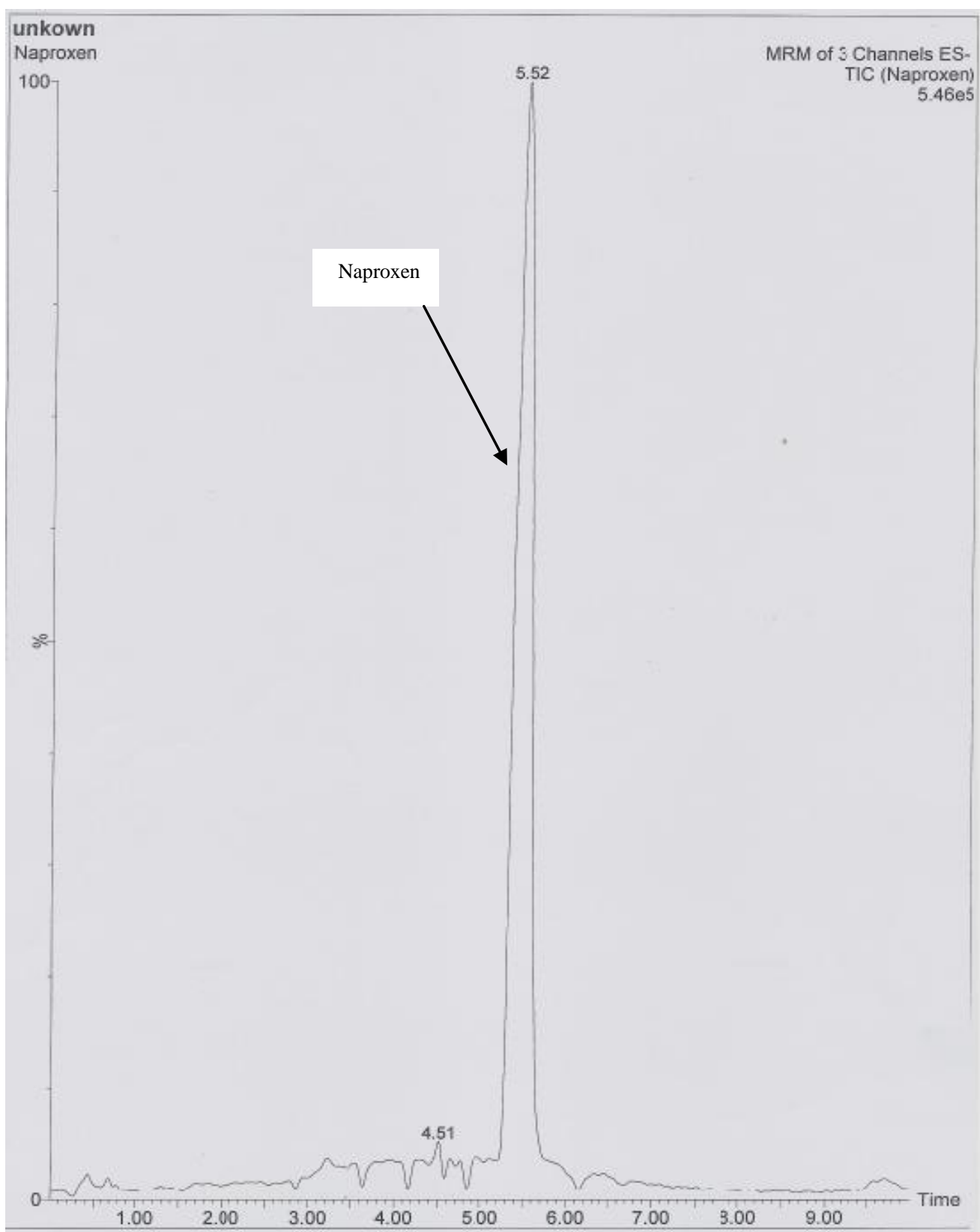

Figure (7): Naproxen chromatogram 2000 pp 
Table (2): Compounds found in qualitative analysis of four samples (cont.)

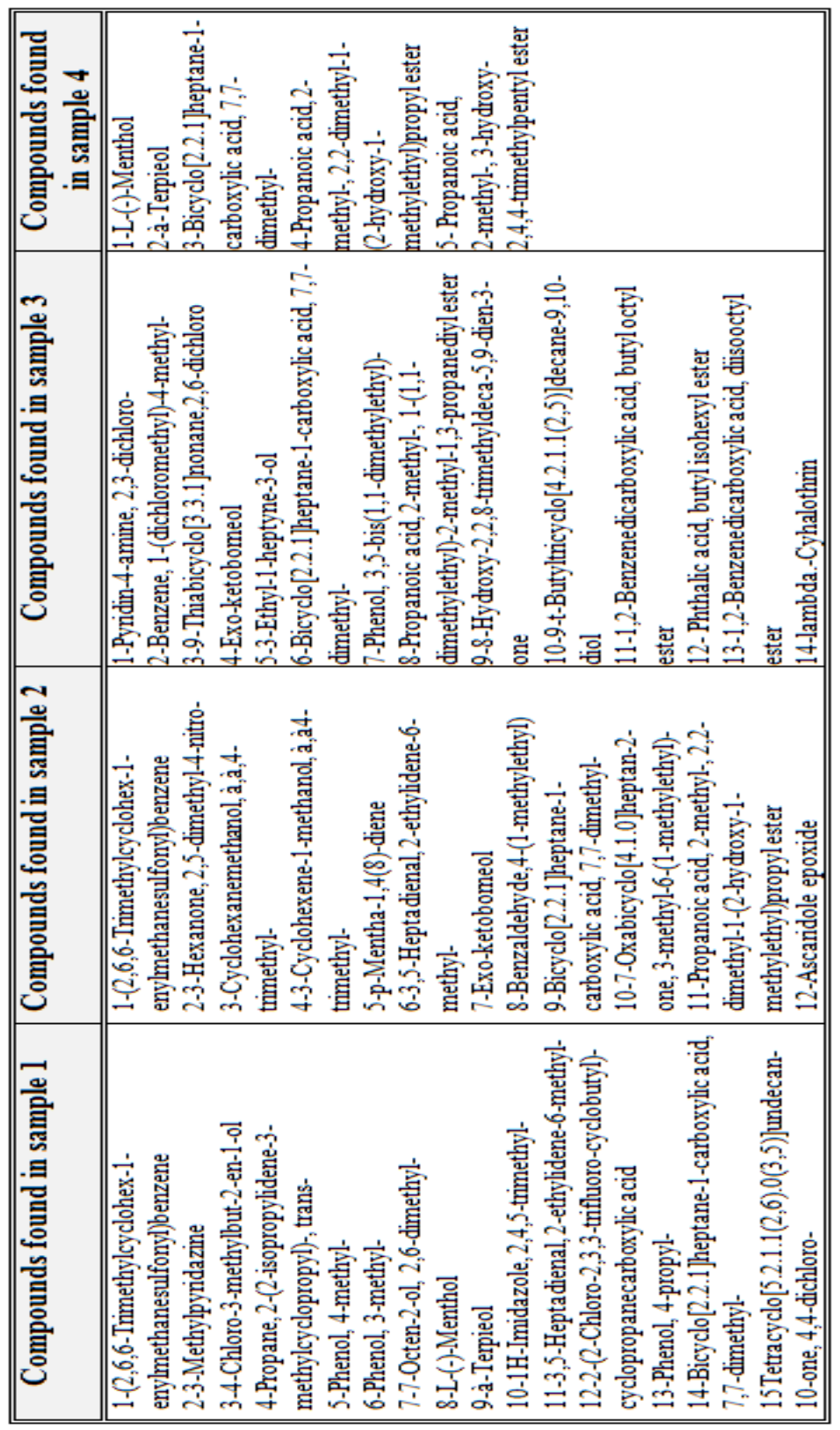


J. Environ. Sci.

Institute of Environmental Studies and Research - Ain Shams University

Table (2): Compounds found in qualitative analysis of four samples (cont.)

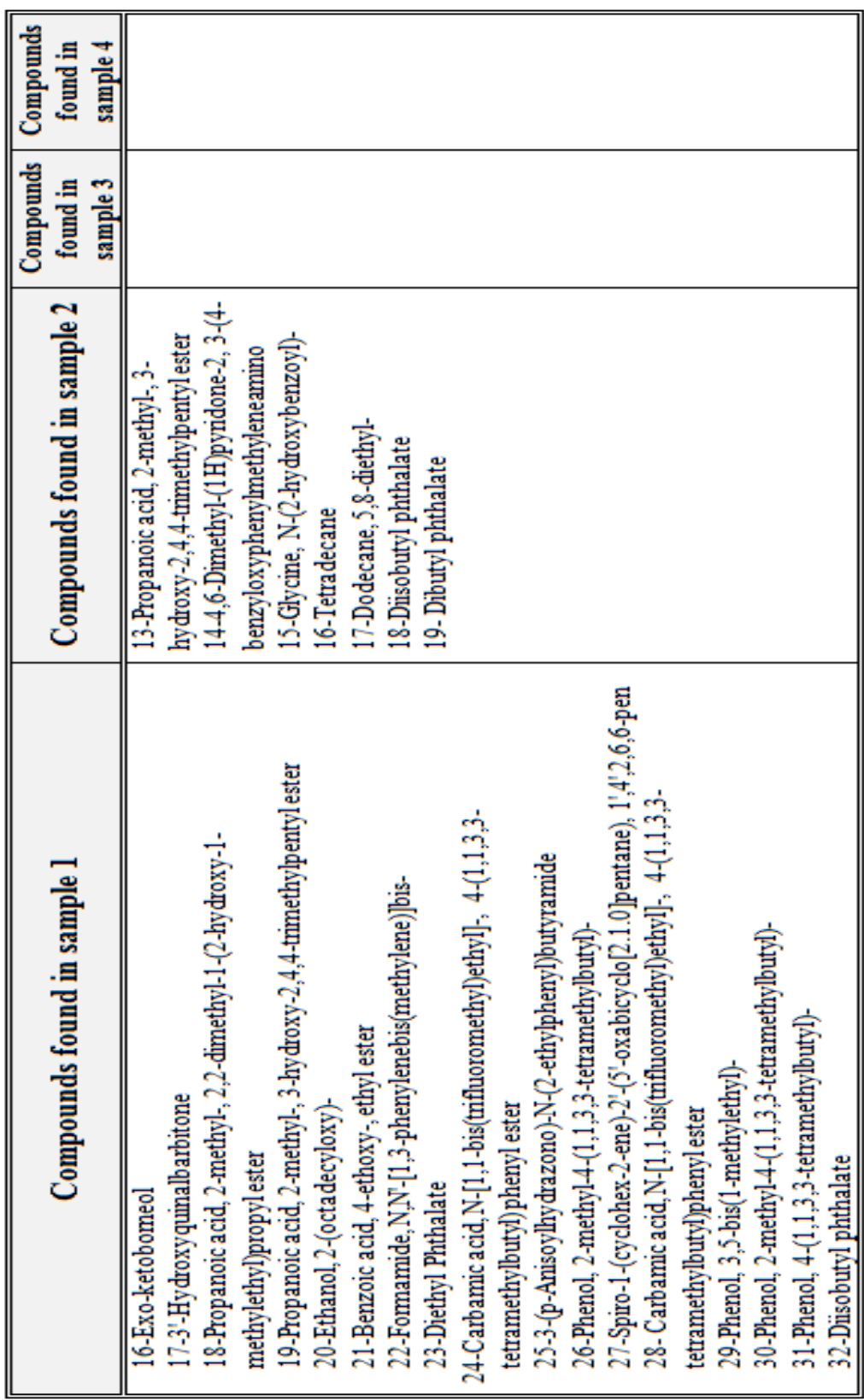


Table (3): Concentration in $(\mathrm{ng} / \mathrm{ml})$ of 4 analytes in wastewater of a pharmaceutical and chemical industries facility

\begin{tabular}{|c|c|c|c|c|}
\hline \multirow{2}{*}{ Sample } & Paracetamol & Caffeine & Dexamethasone & Naproxen \\
\cline { 2 - 5 } & $\begin{array}{c}\text { conc. } \\
(\mathbf{n g} / \mathbf{m l})\end{array}$ & $\begin{array}{c}\text { conc. } \\
(\mathbf{n g} / \mathbf{m l})\end{array}$ & $\begin{array}{c}\text { conc. } \\
(\mathbf{n g} / \mathbf{m l})\end{array}$ & $\begin{array}{c}\text { conc. } \\
(\mathbf{n g} / \mathbf{m l})\end{array}$ \\
\hline Sample1 & 7325 & 9437 & 254 & 2000 \\
\hline Sample2 & 890 & 1750 & 8 & 1700 \\
\hline Sample3 & 38 & 25 & 84 & 0 \\
\hline Sample4 & 270 & 450 & 11 & 0 \\
\hline
\end{tabular}

As shown in table 3 the Quantitative analysis of water sample in agreement with (Rashed et al., 2015) whom reported the presence of caffeine at conc. $9356 \mathrm{ng} / \mathrm{ml}$, paracetamol at conc. $7216 \mathrm{ng} / \mathrm{ml}$ and dexamethasone at conc. $245 \mathrm{ng} / \mathrm{ml}$ in the wastewater of different pharmaceutical industrial surrounding areas .This results also in agreement with (Salgado et al., 2010; Sim et al., 2011 and Yu et al., 2013) ) as they reported the presence of caffeine at conc. 4-19 $\mathrm{ng} / \mathrm{ml}$. In our study the effluent concentration of caffeine was $9437 \mathrm{ng} / \mathrm{ml}$ which reported 500 fold higher than recommended in world wide. In case of paracetamol concentration in wastewater was reported in range from undetected to $97.5 \mathrm{ng} / \mathrm{ml}$ (Behera et al., 2011; Sim et al., 2011; Yu et al., 2013), in our study the effluent concentration of paracetamol was $7325 \mathrm{ng} / \mathrm{ml}$ which reported 70 fold higher than recommended in world wide and when naproxen exposed to sunlight it's converted into two related compounds these photodegradants are predicted to be more toxic than naproxen because they have lower polarity . 
J. Environ. Sci.

Institute of Environmental Studies and Research - Ain Shams University

\section{REFERENCES}

Abdel Maged, E.M. \& Al-Dardery, E.M. (2001): WATER, Al-Dar AlSudania lel Kotob, Khartom, Sudan, Vol.2, p. 99.

Al-Ananza, K.M. (2010): pharmaceutical residues new threat to the environment, paper presented at the Conference, Kuwaiti green line environmental group, Kuwait 23/10/2010.

Barnes, K.K.; Christenson, S.C.; Kolpin, D.W.; Focazio, M.J.; Furlong, E,T; Zaugg, S.D; Meyer, M.T. \& Barber, L.B (2004): Pharmaceuticals and Other Organic Waste Water Contaminants Within a Leachate Plume Downgradient of a Municipal Landfill Ground Water Monitoring and Remediation 24, (2):119 -126.

Behera, S.K.; Kim, H.W.; Oh J.E. \& Park, H.S. (2011): Occurrence and removal of antibiotics, hormones and several other pharmaceuticals in wastewater treatment plants of the largest industrial city of Korea. Science of the Total Environment, 409, 4351-4360.

Brosius, C. (2011): determination of a broad range of selected pharmaceuticals in the southern ocean by ultra-performance liquid chromatography-tandem mass spectrometry; Departmental Honors Thesis University of Tennessee at Chattanooga, pp. 29-31

Corcoran, J.; Winter, M.J. \& Tyler, C.R. (2010): Pharmaceuticals in the aquatic environment: a critical reviewof the evidence for health effects in fish. Crit Rev Toxicol. 40:287-304.

Deegan, A. M.; Shaik, B.; Nolan, K.; Urell, K.; Oelgemöller, M.; Tobin, J. \& Morrissey, A. (2011): Treatment options for wastewater effluents from pharmaceutical Companies. Int. J. Environ. Sci. Tech., 8 (3), 649-666.

Enick, O. \& Moore, M. (2007): Assessing the assessments:Pharmaceuticals in the environment. Environ. Impact. Asses., 27 (8) : 707-729 . 
Helmy, A.H. (2009): Monitoring \& Treatment of Total Organic Halogen Compounds In Drinking water, MSc thesis, Institute of Environmental Studies \& Research Ain Shams University, Cairo, Egypt.

Jones, O.A.H.; Voulvoulis, N. \& Lester, J. N. (2005): Human Pharmaceuticals in Wastewater Treatment Processes, Critical Reviews in Environmental Science and Technology, 35:401-427.

Kolpin, D.W.; Furlong, E.T.; Meyer, M.T.; Thurman, E.M.; Zaugg, S.D.; Barber, L.B. \& Buxton, H.T. (2002): Pharmaceuticals, Hormones, and Other Organic Wastewater Contaminants in U.S. Streams, 1999-2000: A National Reconnaissance, Environ. Sci. Technol., $36,1202-1211$

Luo, Y.; Guo, W.; Ngo H.H.; Nghiem, L.D.; Ibney Ha F.; Zhang, J.; Liang, S. \& Wang, X.C. (2014): A review on the occurrence of micropollutants in the aquatic environment and their fate and removal during wastewater treatment. Science of the Total Environment.

Meng, Chin-Kai, (2008): Determination of Pharmaceuticals in Water by SPE and LC/MS/MS in Both Positive and Negative Ion Modes.

Rashed, O.A.; Abdel Wahab, M.B.; Magdy, N. \& Magdy, M.M. (2015): Effect of Dexamethasone, Paracetamol and Caffeine as Pharmaceutical Industrial Wastewater Compounds on Rats, MSc thesis, Institute of Environmental Studies \& Research Ain Shams University, Cairo ,Egypt.

Salgado, R.; Noronha, J.P.; Oehmen, A.; Carvalho, G. \& Reis, M.A. M. (2010): Analysis of 65 pharmaceuticals and personal care products in 5 wastewater treatment plants in Portugal using a simplified analytical methodology. Water Science \& Technology —WST. 62(12): 2862-2871

Shalini, K.; Anwer, Z.; Sharma, P.K.; Garg, V.K. \& Kumar, N. (2010): A Review on Pharma Pollution. Int.J. PharmTech. 2: (4): 22652270 . 
Sim, W.J.; Lee, J.W.; Lee, E.S.; Shin, S.K.; Hwang, S.R. \& Oh, J.E. (2011): Occurrence and distribution of pharmaceuticals in wastewater from households, livestock farms, hospitals and pharmaceutical manufactures.Chemosphere, 82, 179-186

Ternes T.; Bonerz M. \& Schmidt, T. (2001): Determination of neutral pharmaceuticals in wastewater and rivers by liquid chromatography-electrospray tandem mass spectrometry. J Chromatogr A 938: 175-185.

Thomas, P.M. \& Foster, G.D. (2005): Tracking acidic pharmaceuticals, caffeine, and triclosan through the wastewater treatment process, Environmental Toxicology and Chemistry, Vol. 24,(1), 25-30.

Van der Aa NGFM; Kommer, G.J.; VanMontfoort J.E. \& Versteegh, J.F.M. (2011): Demographic projections of future pharmaceutical consumption in the Netherlands. Water Sci. Tech. , 63: 825-31.

Vulliet, E. \& Cécile Cren-Olivé (2011): Screening of pharmaceuticals and hormones at the regional scale, in surface and groundwaters intended to human consumption.J. Environmental Pollution, 159, 2929-2934.

Yu, D.J.; Yi, X.L.; Ma, Y.F.; Yin, B.; Zhuo, H.L.; Li, J. \& Huang, Y.F. (2009): Effects of administration mode of antibiotics on antibiotic resistance of Enterococcus faecalis in aquatic ecosystems. Chemosphere 76, 915-920.

Yu, Y.; Wu, L. \& Chang, A.C. (2013): Seasonal variation of endocrine disrupting compounds, pharmaceuticals and personal care products in wastewater treatment plants. Science of the Total Environment, 442, 310-316. 


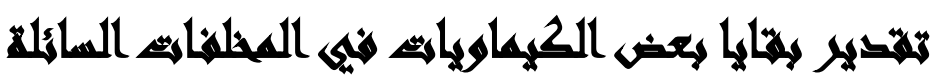 المناعامي الكوائية}

[1]

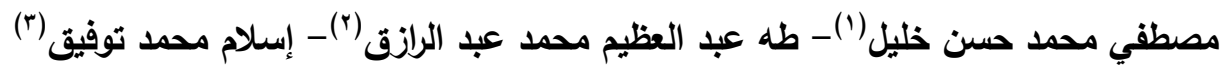

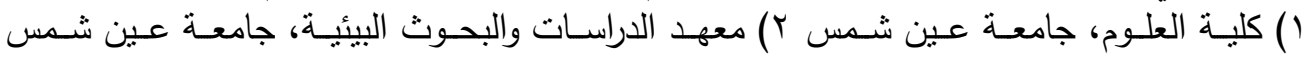
r) شركة النيل للأدوية والصناعات الكيماوية (الثركة القابضة للادوية

\section{المستخلص}

إن الانتشار الواسع المدى للادوية والمركبات الصيدلانية بدأ يجذب الانتباه كملوثات مائية

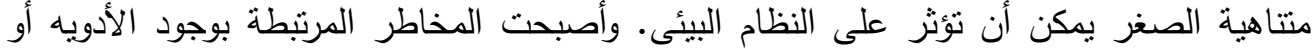

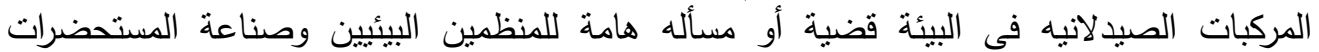
الصيدلانية نتيجة لعدم التخلص الكامل لنفايات الأدوية ونواتج تفاعلاتها الموجودة في مياه الصنات الصرف. وتتثمل هذه الدراسة أنواع مختلفة من مجموعات الألتدية الأدية. تهدف الدراسة الي تقدير بعض متنقيات الأدوية والكيماويات في المخلفات السائلة للصناعات

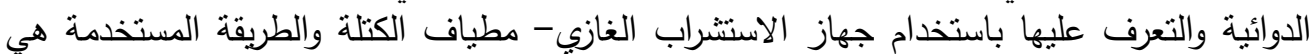
EPA 625 وكذللك يتم تحديد تركيز هذه المتبقيات فى مياه الصرف الصناعى باستخدام جهاز

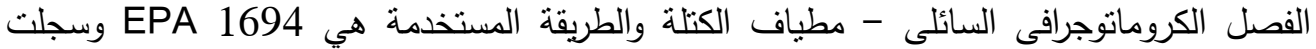
الدراسة تواجد أنواع مختلفة من متنقيات الادوية والكيماويات بتركيزات مختلفة . 